\title{
An Update on CARD Only Proteins (COPs) and PYD Only Proteins (POPs) as Inflammasome Regulators
}

\author{
Savita Devi ${ }^{1}$, Christian Stehlik ${ }^{1,2, *(1)}$ and Andrea Dorfleutner ${ }^{1,3, *}$ \\ 1 Department of Pathology and Laboratory Medicine, Cedars Sinai, Los Angeles, CA 90048, USA; \\ Fnu.SavitaDevi@cshs.org \\ 2 Department of Biomedical Sciences, and Samuel Oschin Comprehensive Cancer Institute, Cedars Sinai, \\ Los Angeles, CA 90048, USA \\ 3 Department of Biomedical Sciences, Cedars Sinai, Los Angeles, CA 90048, USA \\ * Correspondence: christian.stehlik@cshs.org (C.S.); andrea.dorfleutner@cshs.org (A.D.); \\ Tel.: +1-424-315-2670 (C.S.); +1-424-315-2397 (A.D.)
}

Received: 1 September 2020; Accepted: 17 September 2020; Published: 20 September 2020

\begin{abstract}
Inflammasomes are protein scaffolds required for the activation of caspase- 1 and the subsequent release of interleukin (IL)-1 $\beta$, IL-18, and danger signals, as well as the induction of pyroptotic cell death to restore homeostasis following infection and sterile tissue damage. However, excessive inflammasome activation also causes detrimental inflammatory disease. Therefore, extensive control mechanisms are necessary to prevent improper inflammasome responses and inflammatory disease. Inflammasomes are assembled by sequential nucleated polymerization of Pyrin domain (PYD) and caspase recruitment domain (CARD)-containing inflammasome components. Once polymerization is nucleated, this process proceeds in a self-perpetuating manner and represents a point of no return. Therefore, regulation of this key step is crucial for a controlled inflammasome response. Here, we provide an update on two single domain protein families containing either a PYD or a CARD, the PYD-only proteins (POPs) and CARD-only proteins (COPs), respectively. Their structure allows them to occupy and block access to key protein-protein interaction domains necessary for inflammasome assembly, thereby regulating the threshold of these nucleated polymerization events, and consequently, the inflammatory host response.
\end{abstract}

Keywords: AIM2 like receptor; ALR; ASC; caspase-1; CARD; caspase recruitment domain; COP; POP; PYD; PYRIN domain; inflammasome; interleukin-1; NLR; Nod-like receptor

\section{Introduction}

Inflammasomes represent a central component of the innate immune system and their discovery in 2002 started a tremendous effort to delineate the molecular mechanisms of inflammasome signaling and the downstream consequences [1]. Inflammasomes are multimeric protein scaffolds, comprised of an upstream cytoplasmic pattern recognition receptor (PRR), an adaptor and a downstream effector, which are assembled upon the sensing of pathogen associated molecular patterns (PAMPs) or damage associated molecular pattern (DAMPs). Recruitment of the adaptor to the activated PRR allows effector recruitment, followed by its activation and substrate cleavage. The effector caspase- 1 cleaves interleukin (IL)-1 $\beta$, IL-18, and gasdermin D (GSDMD), resulting in cytokine release and the induction of pyroptotic cell death to eliminate infections and restore homeostasis [1-4].

\section{Inflammasome Sensors}

Several cytosolic PRRs have been identified as sensors for canonical inflammasomes and the best studied are Nod like receptor (NLR) family pyrin domain (PYD)-containing 1 (NLRP1), NLRP3, neuronal apoptosis inhibitory proteins (NAIPs)/NLR caspase recruitment domain (CARD) 
containing 4 (NLRC4), absent in melanoma 2 (AIM2), and Pyrin [1,5-21]. NLRP3 consists of an N-terminal PYD for adaptor protein binding, a central NACHT domain containing NTPase activity involved in oligomerization and regulatory C-terminal leucine rich repeats (LRRs). NLRP3 responds to heterogeneous stimuli, including crystalline substances, microbial components, nucleic acids, extracellular ATP, membrane damaging toxins, membrane pore formation, organelle damage and ion imbalance [22-24]. The unifying mechanism is still elusive, but all stimuli trigger cellular stress resulting in $\mathrm{K}^{+}, \mathrm{Cl}^{-}, \mathrm{Ca}^{++}$ion fluxes, mitochondrial, lysosomal, and trans Golgi network disruption, and metabolic changes [24]. Therefore, NLRP3 has a central role by sensing cellular perturbations during sterile inflammation and infection. NLRP1 was the first described inflammasome, and while human NLRP1 consists of a function to find domain (FIIND) and a C-terminal CARD in addition to the domains present in NLRP3, the three mouse paralogous genes lack the PYD [1]. NLRP1 is unique, as it is activated by a functional degradation mechanism and is therefore a sensor for pathogen activity, rather than sensing a specific PAMP. Activation occurs by the $\mathrm{N}$-end rule degradation pathway, which removes the autoinhibitory N-terminal domain $[18,19,25]$. Autoproteolysis at the FIIND prevents degradation of the C-terminal FIIND-CARD fragment, which then functions as a caspase-1-activating scaffold [25-28]. $\mathrm{N}$-end rule degradation is triggered by the Bacillus anthracis endopeptidase anthrax lethal toxin or by the Shigella flexneri E3 ubiquitin ligase ipaH7.8 [18,19,29]. The NAIP-NLRC4 inflammasome is activated by bacterial flagellin and components of the bacterial type III secretion system (T3SS) [9-11,20,21,30-32]. However, NLRC4 is not the direct sensor, bu partners with upstream NAIP proteins, which determine the bacterial ligand specificity of the NLRC4 inflammasome [20,21,33-35]. While mice encode seven NAIP proteins, with NAIP1 and NAIP2 detecting the T3SS rod and needle proteins, respectively and NAIP5 and NAIP6 collectively detecting flagellin by their NACHT, humans encode only a single NAIP protein recognizing both the T3SS needle protein and flagellin [20,21,33-40]. AIM2 has a distinct domain architecture from NLRs and functions as a universal, cytosolic dsDNA sensor [12-15]. It consists of an N-terminal PYD and a C-terminal HIN-200 domain and detects cytosolic dsDNA in a sequence independent, but length dependent manner through the HIN-200 domain [41-43]. Comparable to NLRs, AIM2 also exists in an autoinhibited conformation in naïve cells, where the PYD blocks the HIN-200 domain, and this autoinhibition is released by interaction of the HIN-200 domain with dsDNA by electrostatic interaction [15]. During homeostasis, DNA is absent from the eukaryotic cytoplasm but if DNA is present, it acts as a danger signal to alert the innate immune system. However, DNA might accumulate inside the cytosol following nuclear membrane damage or following ionizing radiation exposure, which also leads to AIM2 activation [44,45]. Pyrin is the other guard-type sensor, which detects pathogen activity or cell damage as a consequence of toxin-mediated impairment of the RhoA GTPase activity. Also, cellular defects in an upstream pathway, such as mutations, that inevitably prevent RhoA GTPase activity, can lead to Pyrin inflammasome activation [17,46,47]. Pyrin also has a distinct domain architecture compared to NLRs, consisting of a PYD, a B-box type zinc finger domain, a coiled-coil domain and a B30.2/SPRY domain. RhoA activity enables phosphorylation of Pyrin by PKN1 and PKN2 on Ser208 and Ser242, which maintains an inactive conformation by binding to 14-3-3 chaperons [47-50]. Hence, the loss of 14-3-3 binding results in Pyrin inflammasome activation. Pyrin may also detect perturbations of the actin cytoskeleton, as mutations in PSTPIP1, a Pyrin binding partner, WDR1, and ARPC1B that affect actin polymerization, are detected by the pyrin inflammasome [51,52].

Several other, but less well characterized, PRRs have also been implicated in the formation of an inflammasome, including NLRP2, NLRP6, NLRP7, NLRP9b, NLRP12, NLRC5, and IFI16 [53-61]. NLRP2 forms an ATP-sensing inflammasome in astrocytes and neurons and contributes to inflammation in the central nervous system [53,54]. NLRP6 regulates an inflammasome in colonic epithelial cells controlling IL-18-mediated intestinal homeostasis by sensing lipoteichoic acid (LTA) of Gram-positive bacterial membranes $[55,56]$. NLRP7, which is restricted to humans, senses acylated lipopeptides present primarily in Gram-positive bacteria and Mycoplasma spp. [57,62,63]. Nlrp9b assembles an inflammasome in colonic epithelial cells and restricts rotavirus infection by sensing short dsRNA in concert with the 
Dhx9 helicase [58]. NLRP12 senses Yersinia pestis tetra-acylated lipid A, but also regulates NF- $\mathrm{KB}$ and MAPK activation and intestinal homeostasis [59,64-66]. The involvement of NLRC5 in inflammasome activation is still very poorly characterized but it has been suggested to cooperate with NLRP3 in sensing several bacteria [60]. IFI16 is unique, as it may sense the Kaposi sarcoma-associated herpesvirus (KSHV) genome and assembles a nuclear inflammasome in endothelial cells [61].

In addition to the above described canonical inflammasomes, which result in caspase- 1 activation, a non-canonical inflammasome results in the activation of human caspase- 4 and caspase- 5 as well as mouse caspase-11 in response to detecting intracellular lipopolysaccharide (LPS) [67-73]. LPS reaches the cytosol if Gram-negative bacteria evade the phagosome, if LPS is bound by guanylate-binding proteins (GBP) and immunity related GTPases (IRGs) and released from phagosomes, if LPS-containing outer membrane vesicles (OMVs) from extracellular bacteria are taken up by endocytosis, or upon LPS binding to HMGB1 and receptor for advanced glycation endproducts (RAGE) mediated endocytosis [67-69,74-85].

\section{Inflammasome Assembly}

Inflammasome sensors generally exist in an autoinhibited conformation, with the LRR blocking the NACHT-mediated oligomerization, the AIM2-PYD blocking the HIN-200 domain and 14-3-3 chaperon binding reinforcing the inactive Pyrin conformation. Upon PAMP/DAMP or pathogen activity sensing these blocks are released, which enables the recruitment of the adaptor protein apoptosis-associated speck like protein containing a CARD (ASC), and recruitment and activation of caspase-1 [15,47-50,86]. ASC encodes a PYD and a CARD and can therefore be recruited to the PYD or CARD of inflammasome sensors through homotypic PYD-PYD or CARD-CARD interactions [87-89]. Activated inflammasome sensors oligomerize and recruit ASC, causing an increase in the local ASC concentration and nucleation of ASC polymerization, which then proceeds by a prion-like, self-perpetuating mechanism. Therefore, ASC polymerization is a critical, non-reversible step in initiating inflammasome responses [90-93]. Subsequently, CARD-CARD mediated recruitment of the effector protease caspase-1 by ASC or by direct binding to the CARD of NLRCs and NLRP1, induces nucleation of caspase-1 polymerization, caspase-1 proteolysis, and induced proximity-mediated auto-activation [94-99]. Some variations from this mechanism exist, as neither NLRP1 nor NLRC4 require ASC, but its presence enhances inflammasome responses. Nevertheless, also NLRC4 activation occurs by nucleated polymerization, with a single bacterial PrgJ-activated NAIP2 or flagellin-activated NAIP5, nucleating NLRC4 polymerization. This scaffold, consisting of one NAIP molecule and 10-12 NLRC4 molecules, promotes continuous oligomerization and formation of new nucleation/oligomerization surfaces to further activate NLRC4 and caspase-1 [100-102]. NLRP1-mediated caspase-1 activation proceeds by a distinct and unique mechanism. As described above, autoproteolytic cleavage between the two FIIND subdomains, ZU5 and UPA, and proteasomal degradation of the NLRP1 N-terminus, releases the C-terminal UPA-CARD fragment, which self-assembles into a caspase-1 activating scaffold [19]. These aggregates of polymerized inflammasome scaffolds can be observed in cells as a cytosolic speck-like structure ranging from $0.8-1 \mu \mathrm{m}$ in diameter [103,104]. A major function of caspase- 1 is the proteolytic processing and maturation of the pro-inflammatory cytokines pro-IL- $1 \beta$ and pro-IL-18, prompting the release of their bioactive forms [105-107]. Both cytokines are lacking a classical signal peptide, but caspase- 1 mediated removal of the pro-peptide allows for the enrichment of IL-1 $\beta$ from the cytosol to PIP2-enriched plasma membrane ruffles, likely via cleavage of the endosome autoantigen 1 and a polybasic motif in the cytokines [108,109]. Release occurs from living cells through membrane pores and during a lytic type of inflammatory cell death called pyroptosis [108-111]. Pyroptosis also leads to the release of polymerized ASC particles, which are phagocytized by neighboring cells and act as DAMP to propagate and further amplify inflammasome responses [103,112,113]. Pyroptosis is induced following proteolytic cleavage of gasdermin-D (GSDMD) at Asp275 in the linker, thereby releasing the N-terminal fragment (GSDMD-N) from the auto-inhibitory C-terminal fragment $[114,115]$. GSDMD-N then binds to membrane lipids, primarily cardiolipin and phosphatidylinositol, and polymerizes to create membrane pores [116-121]. Cardiolipin is also present 
in the inner mitochondrial membrane, and consequently, GSDMD-N also permeabilizes mitochondrial membranes, leading to release of cytochrome-c and subsequent caspase-3 activation to amplify inflammasome responses [122]. Moreover, cardiolipin is also present on bacterial membranes, which can be directly lysed by GSDMD-N [119]. Pyroptosis has long been considered a cell death pathway directed by caspase-1. However, in response to cytosolic lipopolysaccharide (LPS), the non-canonical inflammasome caspases related to caspase- 1 , namely human caspase- 4 and caspase- 5 and mouse caspase- 11 , also activate pyroptosis, but not cytokine processing $[68,69,74,85]$. Nevertheless, activation of the non-canonical inflammasome licenses the canonical NLRP3 inflammasome for cytokine release [68,71]. This step involves a caspase- 11 and caspase-4-mediated reduction of intracellular $\mathrm{K}^{+}$levels, which is a common canonical NLRP3 inflammasome activating step. Proteolytic cleavage of pannexin- 1 by active caspase- 11 or caspase-4 mediates ATP release, which activates the ATP-gated P2X7 channel, and promotes ion flux [71,123-125]. However, this mechanism has recently been questioned and attributed to NLRP3 activation during apoptosis, but not pyroptosis [126]. In addition, activation of ROS and transient receptor potential channel 1 (TRPC1) may also be involved [127,128].

In addition to pathogen and danger signal-activated inflammasomes, mutations and allelic variations in several inflammasome sensors, including NLRP1, NLRP3, NLRP7, NLRP12, NLRC4, AIM2, and Pyrin, have been implicated in an increasing spectrum of autoinflammatory diseases. Alterations of the sensor sequence can lead to uncontrolled inflammasome activation, which is uncoupled from a PAMP or DAMP, but causes or at least contributes to excessive pyroptosis and cytokine release [129-135]. Therefore, a firm regulation of inflammasome responses is imperative for preventing detrimental consequences. Identification of new regulatory mechanisms of caspase-1 activation, like the discovery of novel inhibitory molecules, provides an opportunity to apply this knowledge to translational approaches in the clinic. It is now well established that inflammasome responses proceed by a two-step mechanism of "priming" and "activation", through transcriptional and posttranslational events mediated by specific protein interactions $[24,136,137]$. In addition, inflammasome components are maintained in an inactive conformation by a platitude of molecular mechanisms, including phosphorylation, ubiquitination, s-nitrosylation, sumoylation and a number of binding partners, including NEK7, GBP5, 14-3-3, and others [24,136]. In this review, we summarize the recent developments focusing on a distinct regulatory mechanism of competitive binding, mediated by a family of inflammasome inhibitory proteins, which interfere with the crucial initiating step of nucleated inflammasome assembly, namely the CARD- and PYD-only proteins, COPs, and POPs.

\section{Inflammasome Regulation by PYD-Only Proteins (POPs) and CARD-Only Proteins (COPs)}

Both the PYD and CARD belong to the death domain fold (DDF) superfamily of protein-protein interaction domains, present in proteins regulating cell death and inflammation. They contain a bundle of six anti-parallel $\alpha$-helices with a charged outer surface and a stabilizing hydrophobic core [138-140]. PYDs and CARDs are about 80-90 amino acids long and commonly mediate homotypic interactions, with the charged and hydrophobic surface patches dictating binding specificities. Proteins usually contain a CARD or PYD in combination with other domains to enable complex formation and signaling $[89,141]$. While CARDs can be on the N- or C-terminus of proteins, PYDs are exclusively present at the $\mathrm{N}$-terminus of proteins, and a PYD or a CARD is present in all inflammasome core proteins, including caspases, NLRs, ALRs, ASC, and Pyrin [138]. However, particularly CARD-containing proteins, are also linked to other signaling pathways, including NF- $\mathrm{kB}$ activation. As discussed above, inflammasome assembly relies on PYD- and CARD-mediated protein interactions to nucleate and perpetuate protein polymerization [91-93]. Therefore, small endogenous proteins encoding a single PYD or CARD provide a unique, competitive binding mechanism to interfere with PYD and CARD-mediated interactions of multi-domain proteins, and consequently, interfere with assembly and nucleation of inflammasome components (Figure 1). Furthermore, interference with critical interactions reduces the local density of essential inflammasome components and thereby raises the threshold for inflammasome activation. The PYD-only proteins (POPs) POP1 (PYD containing 1, PYDC1), 
POP2 (PYDC2), and POP3 (PYDC5) can bind to inflammasome sensors or the adaptor ASC, but all three human CARD only proteins (COPs), namely CARD16 (COP/PSEUDO-ICE), CARD17 (INCA), and CARD18 (Iceberg), which share various degrees of similarity to the caspase-1-CARD, can bind to caspase-1 and only CARD16 can also bind to the ASC-CARD. Intriguingly, all COPs and POPs are absent from rat and mouse genomes but are specifically encoded in humans and higher primates [142-144]. The genomic localization of POPs is in close proximity to other PYD containing proteins, while COPs localize in close proximity to the inflammatory caspase cluster and likely originated from a series of exon duplication events and retro-transposition mechanisms (Figure 2) [143]. A fourth POP, POP4, is encoded by the human NLRP2P pseudogene, but only consists of 45 amino acids that form the first two $\alpha$-helices, rather than a complete PYD. Nevertheless, POP4 is able to inhibit the NF-kB pathway, but not inflammasomes [145].

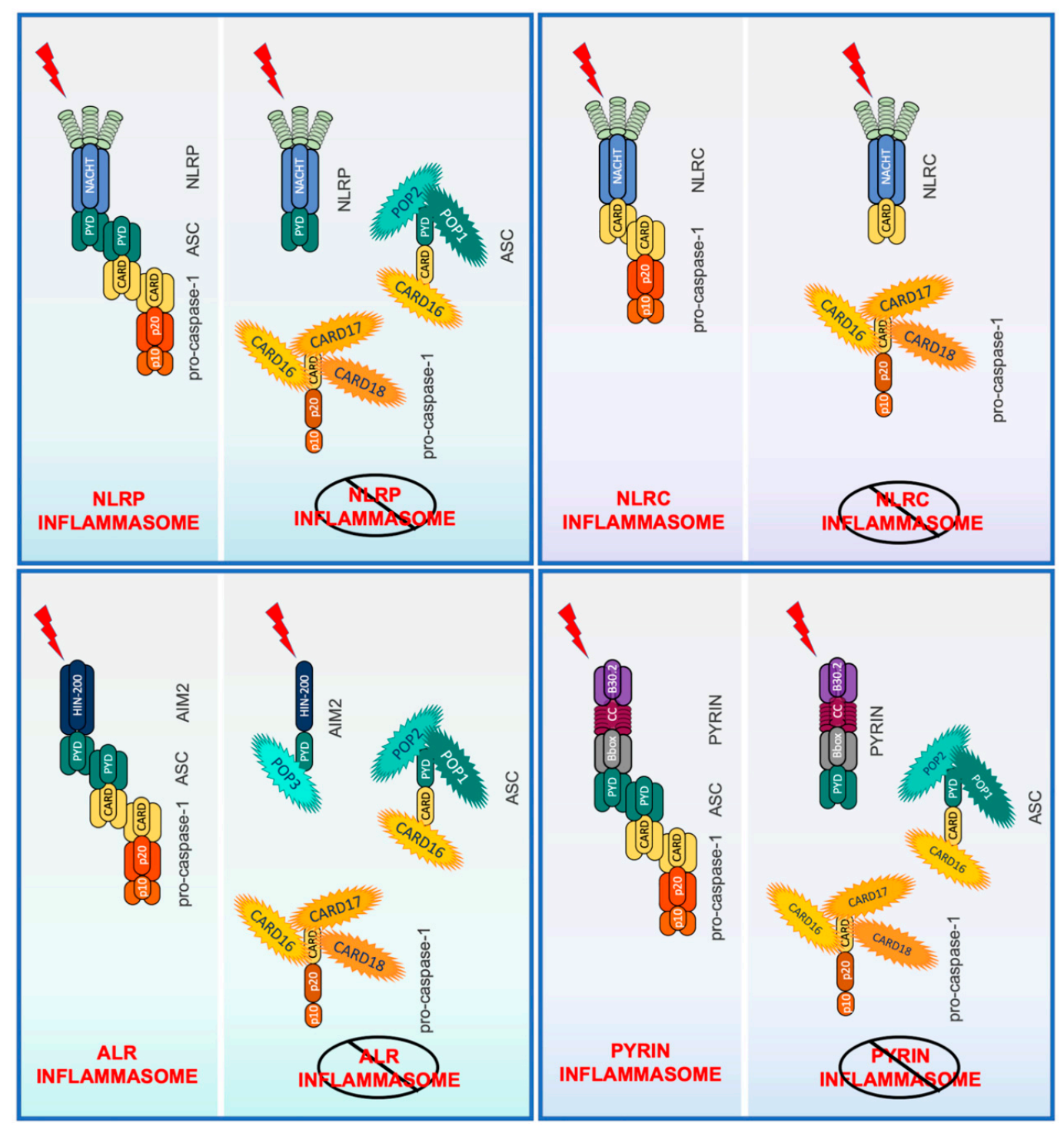

Figure 1. Overview of NLRP, NLRC, Aim2 and pyrin inflammasome regulation by POPs and COPs by interfering with the essential PYD-PYD and CARD-CARD interactions required for inflammasome scaffold assembly and nucleation of ASC and caspase-1 polymerization. 


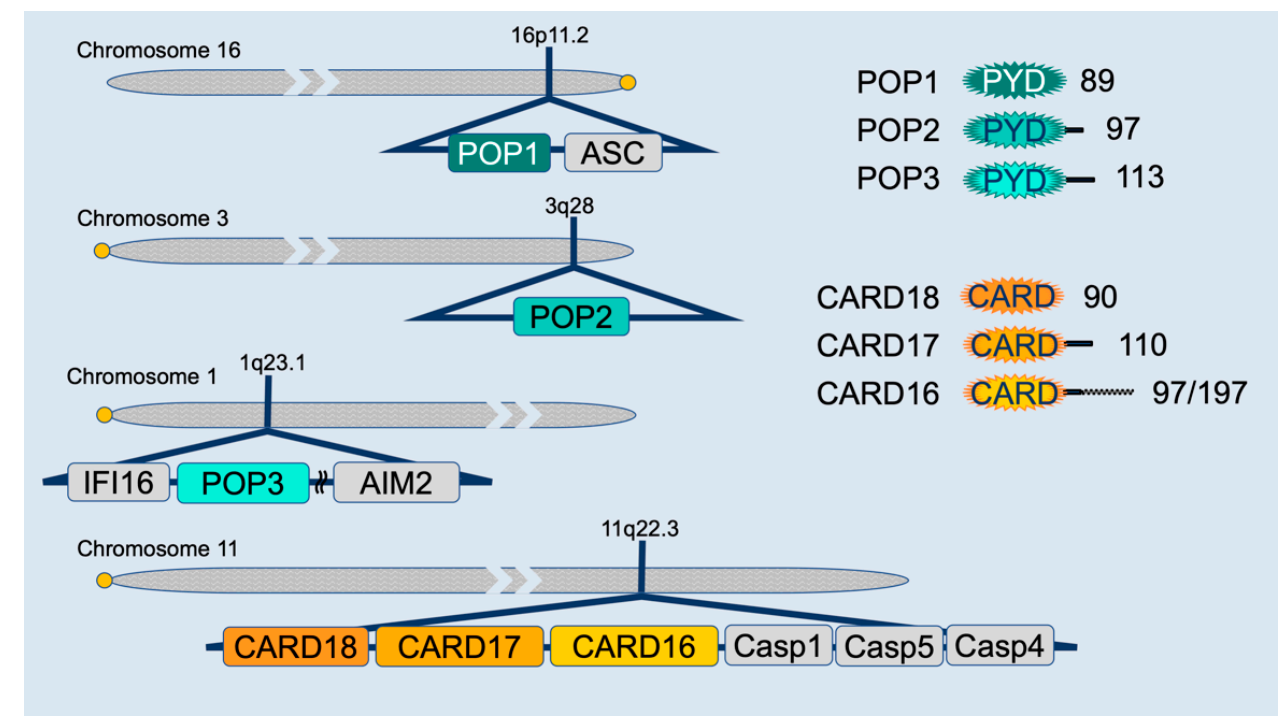

Figure 2. Schemata of POPs and COPs and their chromosomal organization in proximity to key inflammasome components.

\subsection{PYD-Only Protein 1}

POP1 (PYDC1) was the first discovered POP family member and shares $88 \%$ sequence homology and $64 \%$ sequence identity with the PYD of ASC, including the distribution of charged amino acids. Its genomic location is in close proximity to ASC on chromosome 16p12, and likely originated from exon duplication [146]. POP1 encodes a 90 amino acid protein, which localizes diffusely inside the cell. Despite the high similarity to the PYD of ASC, POP1 does not retain its self-polymerization potential, but colocalizes and interacts with ASC. This interaction is mediated by a negative electrostatic potential surface patch from the $\alpha$ helices 1 and 4 in the ASC-PYD and a positive electrostatic potential surface patch from the $\alpha$ helices 2 and 3 in POP1 [147]. Mutation of K20, K21 and R41 in POP1 and E13 and D48 in the ASC-PYD disrupts their interaction, which is the same binding mode responsible for the NLRP3-ASC interactions and therefore may explain the disruptive potential of POP1 on inflammasome assembly [147,148]. While overexpression in HEK293 cells indicated a role of POP1 in regulating NF- $\mathrm{BB}$, subsequent studies with endogenous POP1 identified its main function to be the disruption of canonical inflammasome assembly. In agreement, siRNA mediated POP1 silencing in macrophages enhances inflammasome-mediated IL-1 $\beta$ and IL-18 secretion and pyroptosis [149]. Conversely, increasing POP1 expression results in the inhibition of ASC polymerization and caspase- 1 activation, and eventually prevents IL-1 $\beta$ and IL-18 secretion. Mechanistically, POP1 binding to ASC prevents sensor-induced nucleation of ASC polymerization, the crucial initial step in inflammasome assembly [149]. Furthermore, POP1 also abolishes the inflammasome-driven release of polymerized ASC particles, which act as danger signals for bystander cells to propagate inflammasome responses and are also prevented by POP1 [149]. The murine ASC-PYD is $88 \%$ identical to the human ASC-PYD, and therefore POP1 expression introduced into mouse macrophages was also able to impair inflammasome responses [149]. In vivo, monocyte, macrophage and Dendritic cell (DC)-restricted transgenic POP1 expression from the human CD68 promoter in mice, potently prevents IL-1 $\beta$-mediated systemic inflammation and lethality in response to LPS administration [149]. Moreover, POP1 transgenic mice are completely protected from CAPS caused by the NLRP3-R260W mutation, as evident from a restored normal development and prevention of lethality, usually driven by systemic inflammation. Hence, POP1 can prevent detrimental consequences of inflammatory disease [149]. This was a crucial finding, as PBMCs from CAPS patients have decreased POP1 transcript levels, when compared with healthy controls and a similar trend was also observed in leucocytes from septic patients. Normally, POP1 expression is upregulated by inflammatory stimuli, including IL-1 $\beta$ and IL-18, indicating that POP1 functions in a regulatory feedback loop to potentially prevent excessive inflammasome activation and to 
eventually resolve these responses. Hence, reduced POP1 levels in patients may be insufficient to prevent excessive inflammasome responses, which may suggest that a POP1 based therapy could be a novel treatment approach [149]. Indeed, the administration of recombinant, cell penetrating POP1 ameliorates systemic inflammation [149].

\subsection{PYD-Only Protein 2}

POP2 (PYDC2) displays unique as well as overlapping functions with POP1 and encodes a 97 amino acid protein, which shares $68 \%$ sequence homology with the NLRP2-PYD, 50\% with the NLRP7-PYD and only 37\% similarity with the ASC-PYD [150,151]. NLRP7-PYD-based homology modelling suggested $\alpha$ helices 1 and 4 form a negatively charged surface, which may enable interaction with the positive surface patch of NLRP-PYDs and ASC-PYD, but a positively charged surface is absent in POP2. Similar to POP1, also POP2 expression is upregulated by inflammatory stimuli, and POP2 also co-localizes with ASC and regulates inflammasome assembly and downstream responses, but regulates also activation of NF- КB [150-154]. These two activities can be separated, as $\alpha$ helix 1 is crucial for regulating NF- $\kappa \mathrm{B}$, while the acidic residues E6, D8 and E16 are only essential for inhibiting canonical inflammasomes, but are not required for NF-kB inhibition [152]. Based on binding to ASC, POP2 also broadly blocks canonical inflammasome responses, including caspase-1 activation, pyroptosis, and release of IL-1 $\beta$ and IL-18 [150-154]. Similar to POP1, also POP2 mediates the inflammasome inhibitory effect by preventing the nucleation of ASC polymerization, thereby abrogating inflammasome assembly [154]. However, in addition to solely regulating inflammasome assembly, POP2 also regulates the priming step by regulating TLR-mediated NF- $\mathrm{kB}$ activation. While the exact mechanism remains elusive, dampening the non-canonical IKK $\varepsilon$ and IKB $\alpha$ have been implicated $[150,153,154]$. Also, these pathways are sufficiently conserved between mice and humans, and therefore transgenic expression from the human CD68 promoter, thereby restricting its expression to monocytes, macrophages, and DCs, or elegantly utilizing its endogenous human promoter, phenocopies its function in mice $[153,154]$. Canonical inflammasome-driven systemic inflammation is also ameliorated in vivo [153,154]. Furthermore, POP2 transgenic mice were protected from Francisella tularensis and Streptococcus pneumoniae infection, but not from infection with Salmonella typhimurium, which is sensed by the NLRC4 inflammasome independently of ASC [153]. POP2 transgenic mice demonstrated reduced inflammatory cell infiltration and tissue damage, when compared to littermate controls [153]. Mice show elevated levels of interferon (IFN)- $\gamma$ post infection, due to an increased number of IFN- $\gamma$-secreting macrophages promoting homeostasis between inflammatory cytokine production and IFN- $\gamma$ mediated host defense [153]. Hence, POP2 regulates both, inflammasome priming and activation, while also promoting IFN- $\gamma$ mediated antibacterial activities. Consequently, POP2 may promote host defense without the negative consequences resulting from excessive inflammation.

\subsection{PYD-Only Protein 3}

POP3 (PYDC5) is localized within a type I IFN-inducible genomic cluster encoding all four members of the human PYHIN (HIN-200) family between IF16 and PYHIN1 on chromosome 1q23, which are all characterized by a PYD and one or two C-terminal oligonucleotide binding HIN-200 domain(s), except for POP3, which only encodes a PYD $[144,155,156]$. POP3 encodes a 113 amino acid protein of five $\alpha$ helices, as demonstrated by homology modeling, diverging from other death domain folds. It only shares $19 \%$ sequence identity to ASC, but is $61 \%$ identical to AIM2, also suggesting origination by exon duplication. Indeed, POP3 interacts with the PYD of AIM2 and IFI16, but unlike POP1 and POP2, does not bind to the ASC-PYD. However, comparable to other POPs, POP3 interaction with AIM2 also abolishes the AIM2-ASC complex formation and the resulting nucleation of ASC polymerization [144]. Rather than binding to the adaptor, POP3 directly binds to the sensor, which also results in a much more restricted function, as $\mathrm{POP} 3$ specifically impairs the cytosolic dsDNA-induced inflammasome response without affecting other canonical inflammasomes [144]. POP3, through interactions with AIM2 and IFI16, blocks inflammasome responses induced by infection with dsDNA viruses, including Vaccinia 
virus (AIM2), CMV (AIM2), and KSHV (IFI16) [144]. Similar to POP1 and POP2, the function of POP3 is also sufficiently conserved and human POP3 binds to mouse AIM2 and IFI16 (p204) [144]. Therefore, transgenic mice with monocyte, macrophage and conventional DC-specific POP3 expression, revealed impaired AIM2-mediated antiviral defense through IL-18-mediated IFN- $\gamma$ production in response to MCMV infection, resulting in higher splenic viral titer [144]. However, as expected from cell-based studies, POP3 transgenic mice did not reveal any altered response to MSU crystal injection, which induces an NLRP3 inflammasome-mediated response [144]. Viral infections are potent inducers of type I IFNs, which positively regulate POP3 transcription and protein stability [144]. Therefore, it is quite feasible that POP3 is located within a type I interferon-induced inflammasome feedback loop to eventually resolve cytosolic DNA driven inflammasome responses.

\subsection{CARD16 (COP/Pseudo-ICE)}

There are two isoforms of CARD16, a long and a short isoform, though only the short variant has been studied. The short isoform contains a 91-amino acid CARD and six additional amino acids at the carboxy terminus and the long isoform contains the CARD and 106 additional amino acids at the carboxy terminus $[157,158]$. CARDs are known for their ability to oligomerize and to interact with other CARDs. Accordingly, CARD16 is able to self-oligomerize, similar to the CARD of caspase-1, forming filament-like structures. It also shares $97 \%$ amino acid sequence similarity with, and is able to bind to the CARD of caspase-1 [157-159]. Interestingly, mutation of D27 or R45 within CARD16 to G27 or C45, which are the correlating amino acids within CARD17, resulted in a non-filament forming form of CARD16. Furthermore, CARD16 interacts with the CARD of ASC, co-localizing in perinuclear ASC-specks [159]. Taken together, this suggests that CARD16 could regulate inflammasome assembly, caspase- 1 activation, and cytokine maturation. Indeed, CARD16 was able to function as an inhibitor for IL-1 $\beta$ maturation and secretion, but was also able to induce IL- $1 \beta$ secretion through its ability to bind, aggregate and activate caspase-1, since the non-filament forming mutants of CARD16 were unable to induce IL-1 $\beta$ secretion to the same extent as wildtype CARD16 [157-159]. While inflammasome activation was observed in epithelial Hela cells, inflammasome inhibition was detected in monocytic THP-1 cells $[158,159]$. Hence, the expression of other co-regulators in different cell types might be able to alter the effects of CARD16 on caspase- 1 activation or may depend on CARD16 expression levels. Further evidence for an inhibitory function of CARD16 on caspase- 1 was discovered when RIP2 mediated caspase- 1 activation and IL-1 $\beta$ secretion was blocked by CARD16 [157]. Numerous CARD-containing proteins have been implicated to play a role in the NF- $K B$ signaling pathway, and at least by overexpression in HEK293 cells, CARD16 was able to activate NF- $\kappa B$ [158]. However, further studies will be necessary to better understand the physiological role of CARD16 on inflammasome regulation and NF-KB signaling. Interestingly, among all CARD only proteins, CARD16 shares the highest $(83.8 \%)$ sequence homology with the caspase- 1 promoter region, and therefore CARD16 expression is comparable to caspase-1 expression in lymph nodes, placenta, spleen, bone marrow, PBMCs, and macrophages $[158,159]$.

\subsection{CARD17 (INCA)}

CARD17 encodes a 110 amino acid protein that is $81 \%$ identical to the caspase- 1 CARD [160]. Although self-oligomerization is a very common feature of CARDs, CARD17 is unable to self-oligomerize upon expression in Hela cells. However, reminiscent to CARD16, also CARD17 is able to bind to the CARD of caspase- 1 and interferes with the self-oligomerization of the caspase- 1 CARD, suggesting that CARD17 could have an inhibitory effect on caspase- 1 activation by blocking caspase- 1 self-oligomerization . Indeed, CARD17 is able to block IL-1 $\beta$ maturation and secretion. While CARD16 binds to caspase-1 and ASC, CARD17 did not interact with the ASC-CARD and did not co-localize with ASC in specks $[159,160]$. However, CARD17 was able to interfere with caspase-1 and ASC co-localization in specks and caused disperse caspase-1 localization $[159,160]$. Contrary to CARD16, CARD17 does not affect RIP2-mediated NF-kB activation. Electron microscopy revealed that CARD17 localizes to the tip 
of caspase- 1 oligomeric filaments to cap filaments and prevent further filament elongation, due to the lack of two of the six complementary binding surfaces necessary for nucleating polymerization [161]. Interestingly, CARD17 does not form a stable complex with the CARD of caspase- 1 to sequester the monomeric form but rather caps the oligomeric form [161]. Similar to CARD16, also the upstream promoter regions of CARD17 and Caspase- 1 share 80.2\% sequence homology [159]. However, in spite of the strong promoter homology, the expression profile of CARD17 and caspase- 1 differ, except for the positive regulation by IFN- $\gamma$, suggesting a unique regulation [160].

\subsection{CARD18 (ICEBERG)}

CARD18 was the first identified COP and encodes a 90 amino acid protein with only $52 \%$ homology to the CARD of caspase-1 [158,162]. Its NMR structure has been solved, revealing that $\alpha$ helices, 1,4 , and 6 are comprised of positively charged residues and $\alpha$ helices 2 and 5 are comprised of negatively charged residues comparable to caspase-1. Hence, electrostatic interaction between CARD18 and caspase-1 should be possible $[94,162,163]$. Indeed, CARD18 binds to caspase-1 by CARD-CARD interaction and inhibits caspase-1 oligomerization and activation [158,162]. However, a recent report suggests that CARD18 actually promotes caspase- 1 polymerization and filament formation, thereby activating caspase-1, but without promoting additional IL-1 $\beta$ release [161]. However, expression of CARD18 consistently reduces IL-1 $\beta$ maturation and release in other studies [158,162]. Expression of CARD18 is quite distinct from other COPs, as it is not affected by IFN- $\gamma$ but enhanced by LPS and TNF $[158,162]$. However, more efforts are necessary to clarify the controversial role of CARD18 in regulating inflammasome activation. Interestingly, CARD18 expression can be detected in keratinocytes and is significantly increased in response to inflammatory stimuli. Silencing of CARD18 also decreases the expression of inflammasome components but increases IL-1 $\beta$ secretion in response to inflammatory stimuli, indicating that CARD18 negatively regulates inflammasome activation. Strikingly, the expression of CARD18 is altered in psoriasis, which may contribute to disease pathogenesis [164].

\section{Conclusions}

Tremendous progress has been made in delineating the molecular mechanisms responsible for inflammasome activation, assembly, and the downstream responses, as well as identification of numerous inflammasome activators and regulators. Nucleated polymerization of PYD and CARD-containing inflammasome components emerged as a key step in inflammasome assembly. Hence, the interference of POPs and COPs with this critical step provides a regulatory mechanism for fine tuning inflammasome assembly and activation. In spite of recent advances, COPs and POPs are still largely understudied, and further work is needed to provide deeper insights into the precise contribution of each individual family member and their unique and shared aspects to control inappropriate inflammasome responses. There is evidence that COPs and POPs are lacking in inflammatory diseases. For instance, CAPS and sepsis patients have significantly less POP1 expression in whole blood than healthy controls [149], POP1, POP2, and CARD18 are downregulated in periodontal disease [165] and CARD18 is highly expressed in the epidermis, but expression is lost in lichen planus [166]. Hence, we expect that there is a unique expression pattern of POPs and COPs in different tissues and cell types, either during homeostasis or during inflammatory immune responses. Since the overactivation of inflammasomes is directly associated with an increasing spectrum of inflammatory disorders, we believe that the expression of COPs and POPs is critical to provide a balanced and timely immune response and to maintain homeostasis.

Author Contributions: S.D., C.S. and A.D. wrote this article. All authors have read and agreed to the published version of the manuscript.

Funding: This work was supported by the National Institutes of Health (AI099009 and AR064349 to C.S., AI134030, AI140702 and AI120625 to C.S. and A.D., and AR066739 to A.D.).

Conflicts of Interest: The authors declare no conflict of interest. 


\section{Abbreviations}

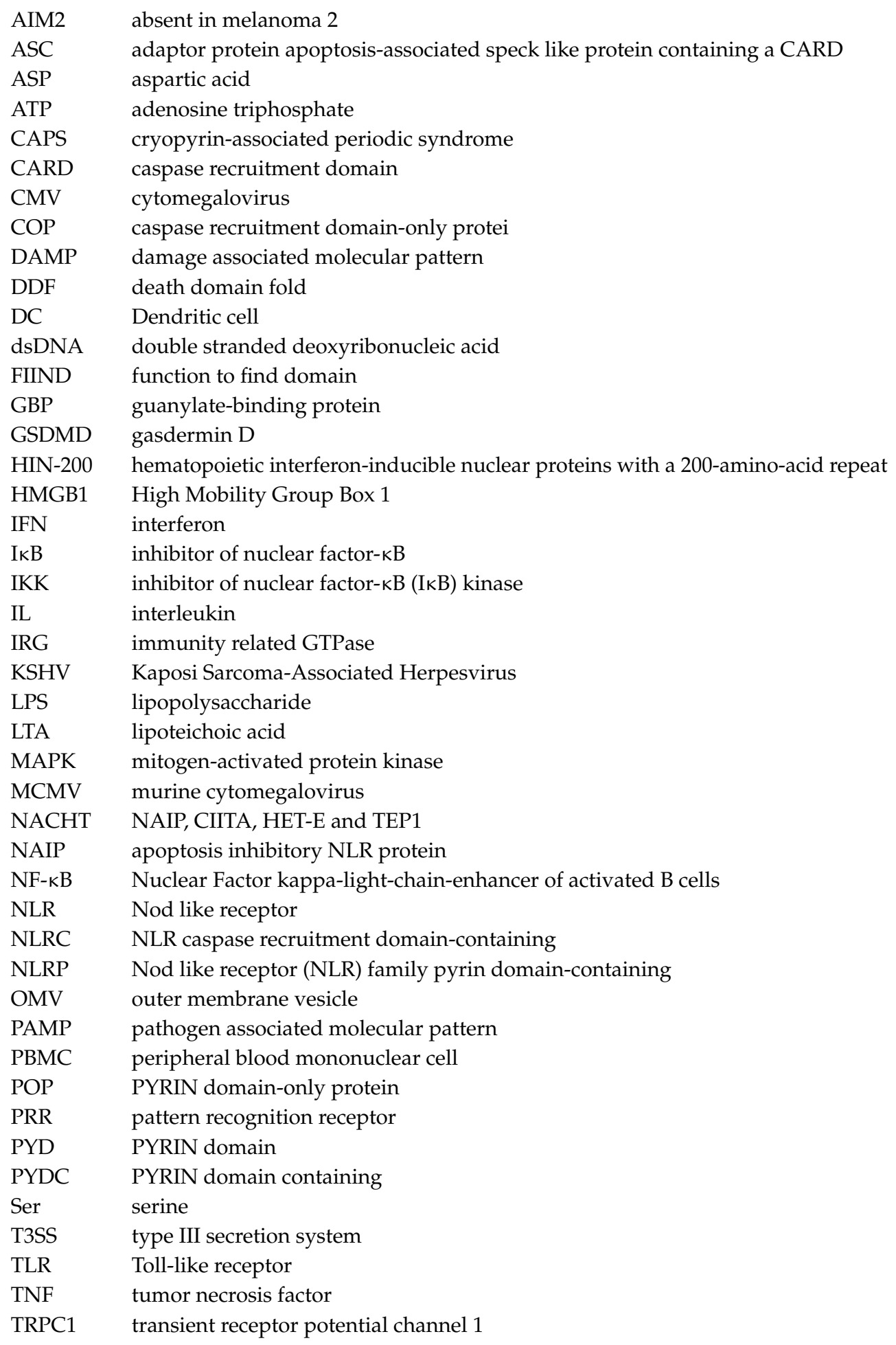

\section{References}

1. Martinon, F.; Burns, K.; Tschopp, J. The inflammasome: A molecular platform triggering activation of inflammatory caspases and processing of proIL-beta. Mol. Cell 2002, 10, 417-426. [CrossRef]

2. Place, D.E.; Kanneganti, T.D. Recent advances in inflammasome biology. Curr. Opin. Immunol. 2018, 50, 32-38. [CrossRef] 
3. Broz, P.; Dixit, V.M. Inflammasomes: Mechanism of assembly, regulation and signalling. Nat. Rev. Immunol. 2016, 16, 407-420. [CrossRef] [PubMed]

4. Khare, S.; Luc, N.; Dorfleutner, A.; Stehlik, C. Inflammasomes and their activation. Crit. Rev. Immunol. 2010, 30, 463-487. [CrossRef]

5. Kanneganti, T.D.; Ozoren, N.; Body-Malapel, M.; Amer, A.; Park, J.H.; Franchi, L.; Whitfield, J.; Barchet, W.; Colonna, M.; Vandenabeele, P.; et al. Bacterial RNA and small antiviral compounds activate caspase-1 through cryopyrin/Nalp3. Nature 2006, 440, 233-236. [CrossRef] [PubMed]

6. Mariathasan, S.; Weiss, D.S.; Newton, K.; McBride, J.; O’Rourke, K.; Roose-Girma, M.; Lee, W.P.; Weinrauch, Y.; Monack, D.M.; Dixit, V.M. Cryopyrin activates the inflammasome in response to toxins and ATP. Nature 2006, 440, 228-232. [CrossRef] [PubMed]

7. Martinon, F.; Petrilli, V.; Mayor, A.; Tardivel, A.; Tschopp, J. Gout-associated uric acid crystals activate the NALP3 inflammasome. Nature 2006, 440, 237-241. [CrossRef]

8. Sutterwala, F.S.; Ogura, Y.; Szczepanik, M.; Lara-Tejero, M.; Lichtenberger, G.S.; Grant, E.P.; Bertin, J.; Coyle, A.J.; Galan, J.E.; Askenase, P.W.; et al. Critical role for NALP3/CIAS1/Cryopyrin in innate and adaptive immunity through its regulation of caspase-1. Immunity 2006, 24, 317-327. [CrossRef]

9. Amer, A.; Franchi, L.; Kanneganti, T.D.; Body-Malapel, M.; Ozoren, N.; Brady, G.; Meshinchi, S.; Jagirdar, R.; Gewirtz, A.; Akira, S.; et al. Regulation of Legionella phagosome maturation and infection through flagellin and host Ipaf. J. Biol. Chem. 2006, 281, 35217-35223. [CrossRef]

10. Franchi, L.; Amer, A.; Body-Malapel, M.; Kanneganti, T.D.; Ozoren, N.; Jagirdar, R.; Inohara, N.; Vandenabeele, P.; Bertin, J.; Coyle, A.; et al. Cytosolic flagellin requires Ipaf for activation of caspase-1 and interleukin 1beta in salmonella-infected macrophages. Nat. Immunol. 2006, 7, 576-582. [CrossRef]

11. Miao, E.A.; Alpuche-Aranda, C.M.; Dors, M.; Clark, A.E.; Bader, M.W.; Miller, S.I.; Aderem, A. Cytoplasmic flagellin activates caspase-1 and secretion of interleukin 1beta via Ipaf. Nat. Immunol. 2006, 7, 569-575. [CrossRef] [PubMed]

12. Burckstummer, T.; Baumann, C.; Bluml, S.; Dixit, E.; Durnberger, G.; Jahn, H.; Planyavsky, M.; Bilban, M.; Colinge, J.; Bennett, K.L.; et al. An orthogonal proteomic-genomic screen identifies AIM2 as a cytoplasmic DNA sensor for the inflammasome. Nat. Immunol. 2009, 10, 266-272. [CrossRef] [PubMed]

13. Fernandes-Alnemri, T.; Yu, J.W.; Datta, P.; Wu, J.; Alnemri, E.S. AIM2 activates the inflammasome and cell death in response to cytoplasmic DNA. Nature 2009, 458, 509-513. [CrossRef] [PubMed]

14. Hornung, V.; Ablasser, A.; Charrel-Dennis, M.; Bauernfeind, F.; Horvath, G.; Caffrey, D.R.; Latz, E.; Fitzgerald, K.A. AIM2 recognizes cytosolic dsDNA and forms a caspase-1-activating inflammasome with ASC. Nature 2009, 458, 514-518. [CrossRef] [PubMed]

15. Roberts, T.L.; Idris, A.; Dunn, J.A.; Kelly, G.M.; Burnton, C.M.; Hodgson, S.; Hardy, L.L.; Garceau, V.; Sweet, M.J.; Ross, I.L.; et al. HIN-200 proteins regulate caspase activation in response to foreign cytoplasmic DNA. Science 2009, 323, 1057-1060. [CrossRef]

16. Chae, J.J.; Cho, Y.H.; Lee, G.S.; Cheng, J.; Liu, P.P.; Feigenbaum, L.; Katz, S.I.; Kastner, D.L. Gain-of-function Pyrin mutations induce NLRP3 protein-independent interleukin-1beta activation and severe autoinflammation in mice. Immunity 2011, 34, 755-768. [CrossRef]

17. Xu, H.; Yang, J.; Gao, W.; Li, L.; Li, P.; Zhang, L.; Gong, Y.N.; Peng, X.; Xi, J.J.; Chen, S.; et al. Innate immune sensing of bacterial modifications of Rho GTPases by the Pyrin inflammasome. Nature 2014, 513, 237-241. [CrossRef]

18. Chui, A.J.; Okondo, M.C.; Rao, S.D.; Gai, K.; Griswold, A.R.; Johnson, D.C.; Ball, D.P.; Taabazuing, C.Y.; Orth, E.L.; Vittimberga, B.A.; et al. N-terminal degradation activates the NLRP1B inflammasome. Science 2019, 364, 82-85. [CrossRef]

19. Sandstrom, A.; Mitchell, P.S.; Goers, L.; Mu, E.W.; Lesser, C.F.; Vance, R.E. Functional degradation: A mechanism of NLRP1 inflammasome activation by diverse pathogen enzymes. Science 2019, 364. [CrossRef]

20. Kofoed, E.M.; Vance, R.E. Innate immune recognition of bacterial ligands by NAIPs determines inflammasome specificity. Nature 2011, 477, 592-595. [CrossRef]

21. Zhao, Y.; Yang, J.; Shi, J.; Gong, Y.N.; Lu, Q.; Xu, H.; Liu, L.; Shao, F. The NLRC4 inflammasome receptors for bacterial flagellin and type III secretion apparatus. Nature 2011, 477, 596-600. [CrossRef] [PubMed]

22. Haneklaus, M.; O'Neill, L.A. NLRP3 at the interface of metabolism and inflammation. Immunol. Rev. 2015, 265, 53-62. [CrossRef] 
23. Kelley, N.; Jeltema, D.; Duan, Y.; He, Y. The NLRP3 Inflammasome: An Overview of Mechanisms of Activation and Regulation. Int. J. Mol. Sci. 2019, 20, 3328. [CrossRef] [PubMed]

24. Swanson, K.V.; Deng, M.; Ting, J.P. The NLRP3 inflammasome: Molecular activation and regulation to therapeutics. Nat. Rev. Immunol. 2019, 19, 477-489. [CrossRef]

25. Chavarria-Smith, J.; Vance, R.E. Direct proteolytic cleavage of NLRP1B is necessary and sufficient for inflammasome activation by anthrax lethal factor. PLoS Pathog. 2013, 9, e1003452. [CrossRef]

26. D'Osualdo, A.; Weichenberger, C.X.; Wagner, R.N.; Godzik, A.; Wooley, J.; Reed, J.C. CARD8 and NLRP1 undergo autoproteolytic processing through a ZU5-like domain. PLoS ONE 2011, 6, e27396. [CrossRef] [PubMed]

27. Finger, J.N.; Lich, J.D.; Dare, L.C.; Cook, M.N.; Brown, K.K.; Duraiswami, C.; Bertin, J.; Gough, P.J. Autolytic proteolysis within the function to find domain (FIIND) is required for NLRP1 inflammasome activity. J. Biol. Chem. 2012, 287, 25030-25037. [CrossRef]

28. Frew, B.C.; Joag, V.R.; Mogridge, J. Proteolytic processing of Nlrp1b is required for inflammasome activity. PLoS Pathog. 2012, 8, e1002659. [CrossRef]

29. Levinsohn, J.L.; Newman, Z.L.; Hellmich, K.A.; Fattah, R.; Getz, M.A.; Liu, S.; Sastalla, I.; Leppla, S.H.; Moayeri, M. Anthrax lethal factor cleavage of Nlrp1 is required for activation of the inflammasome. PLoS Pathog. 2012, 8, e1002638. [CrossRef]

30. Miao, E.A.; Mao, D.P.; Yudkovsky, N.; Bonneau, R.; Lorang, C.G.; Warren, S.E.; Leaf, I.A.; Aderem, A. Innate immune detection of the type III secretion apparatus through the NLRC4 inflammasome. Proc. Natl. Acad. Sci. USA 2010, 107, 3076-3080. [CrossRef]

31. Miao, E.A.; Warren, S.E. Innate immune detection of bacterial virulence factors via the NLRC4 inflammasome. J. Clin. Immunol. 2010, 30, 502-506. [CrossRef] [PubMed]

32. Mariathasan, S.; Newton, K.; Monack, D.M.; Vucic, D.; French, D.M.; Lee, W.P.; Roose-Girma, M.; Erickson, S.; Dixit, V.M. Differential activation of the inflammasome by caspase-1 adaptors ASC and Ipaf. Nature 2004, 430, 213-218. [CrossRef] [PubMed]

33. Ren, T.; Zamboni, D.S.; Roy, C.R.; Dietrich, W.F.; Vance, R.E. Flagellin-deficient Legionella mutants evade caspase-1- and Naip5-mediated macrophage immunity. PLoS Pathog. 2006, 2, e18. [CrossRef] [PubMed]

34. Rauch, I.; Tenthorey, J.L.; Nichols, R.D.; Al Moussawi, K.; Kang, J.J.; Kang, C.; Kazmierczak, B.I.; Vance, R.E. NAIP proteins are required for cytosolic detection of specific bacterial ligands in vivo. J. Exp. Med. 2016, 213, 657-665. [CrossRef] [PubMed]

35. Zhao, Y.; Shi, J.; Shi, X.; Wang, Y.; Wang, F.; Shao, F. Genetic functions of the NAIP family of inflammasome receptors for bacterial ligands in mice. J. Exp. Med. 2016, 213, 647-656. [CrossRef] [PubMed]

36. Rayamajhi, M.; Zak, D.E.; Chavarria-Smith, J.; Vance, R.E.; Miao, E.A. Cutting edge: Mouse NAIP1 detects the type III secretion system needle protein. J. Immunol. 2013, 191, 3986-3989. [CrossRef]

37. Kortmann, J.; Brubaker, S.W.; Monack, D.M. Cutting Edge: Inflammasome Activation in Primary Human Macrophages Is Dependent on Flagellin. J. Immunol. 2015, 195, 815-819. [CrossRef] [PubMed]

38. Katagiri, N.; Shobuike, T.; Chang, B.; Kukita, A.; Miyamoto, H. The human apoptosis inhibitor NAIP induces pyroptosis in macrophages infected with Legionella pneumophila. Microbes Infect. 2012, 14, 1123-1132. [CrossRef]

39. Lightfield, K.L.; Persson, J.; Brubaker, S.W.; Witte, C.E.; von Moltke, J.; Dunipace, E.A.; Henry, T.; Sun, Y.H.; Cado, D.; Dietrich, W.F.; et al. Critical function for Naip5 in inflammasome activation by a conserved carboxy-terminal domain of flagellin. Nat. Immunol. 2008, 9, 1171-1178. [CrossRef]

40. Tenthorey, J.L.; Kofoed, E.M.; Daugherty, M.D.; Malik, H.S.; Vance, R.E. Molecular basis for specific recognition of bacterial ligands by NAIP/NLRC4 inflammasomes. Mol. Cell 2014, 54, 17-29. [CrossRef]

41. Albrecht, M.; Choubey, D.; Lengauer, T. The HIN domain of IFI-200 proteins consists of two OB folds. Biochem. Biophys. Res. Commun. 2005, 327, 679-687. [CrossRef] [PubMed]

42. Jin, T.; Perry, A.; Jiang, J.; Smith, P.; Curry, J.A.; Unterholzner, L.; Jiang, Z.; Horvath, G.; Rathinam, V.A.; Johnstone, R.W.; et al. Structures of the HIN domain:DNA complexes reveal ligand binding and activation mechanisms of the AIM2 inflammasome and IFI16 receptor. Immunity 2012, 36, 561-571. [CrossRef] [PubMed]

43. Matyszewski, M.; Morrone, S.R.; Sohn, J. Digital signaling network drives the assembly of the AIM2-ASC inflammasome. Proc. Natl. Acad. Sci. USA 2018, 115, E1963-E1972. [CrossRef] [PubMed] 
44. Di Micco, A.; Frera, G.; Lugrin, J.; Jamilloux, Y.; Hsu, E.T.; Tardivel, A.; De Gassart, A.; Zaffalon, L.; Bujisic, B.; Siegert, S.; et al. AIM2 inflammasome is activated by pharmacological disruption of nuclear envelope integrity. Proc. Natl. Acad. Sci. USA 2016, 113, E4671-E4680. [CrossRef] [PubMed]

45. Hu, B.; Jin, C.; Li, H.B.; Tong, J.; Ouyang, X.; Cetinbas, N.M.; Zhu, S.; Strowig, T.; Lam, F.C.; Zhao, C.; et al. The DNA-sensing AIM2 inflammasome controls radiation-induced cell death and tissue injury. Science 2016, 354, 765-768. [CrossRef] [PubMed]

46. Akula, M.K.; Shi, M.; Jiang, Z.; Foster, C.E.; Miao, D.; Li, A.S.; Zhang, X.; Gavin, R.M.; Forde, S.D.; Germain, G.; et al. Control of the innate immune response by the mevalonate pathway. Nat. Immunol. 2016, 17, 922-929. [CrossRef]

47. Park, Y.H.; Wood, G.; Kastner, D.L.; Chae, J.J. Pyrin inflammasome activation and RhoA signaling in the autoinflammatory diseases FMF and HIDS. Nat. Immunol. 2016, 17, 914-921. [CrossRef]

48. Gao, W.; Yang, J.; Liu, W.; Wang, Y.; Shao, F. Site-specific phosphorylation and microtubule dynamics control Pyrin inflammasome activation. Proc. Natl. Acad. Sci. USA 2016, 113, E4857-E4866. [CrossRef]

49. Masters, S.L.; Lagou, V.; Jeru, I.; Baker, P.J.; Van Eyck, L.; Parry, D.A.; Lawless, D.; De Nardo, D.; Garcia-Perez, J.E.; Dagley, L.F.; et al. Familial autoinflammation with neutrophilic dermatosis reveals a regulatory mechanism of pyrin activation. Sci. Transl. Med. 2016, 8, 332ra45. [CrossRef]

50. Moghaddas, F.; Llamas, R.; De Nardo, D.; Martinez-Banaclocha, H.; Martinez-Garcia, J.J.; Mesa-Del-Castillo, P.; Baker, P.J.; Gargallo, V.; Mensa-Vilaro, A.; Canna, S.; et al. A novel Pyrin-Associated Autoinflammation with Neutrophilic Dermatosis mutation further defines 14-3-3 binding of pyrin and distinction to Familial Mediterranean Fever. Ann. Rheum. Dis. 2017, 76, 2085-2094. [CrossRef]

51. Shoham, N.G.; Centola, M.; Mansfield, E.; Hull, K.M.; Wood, G.; Wise, C.A.; Kastner, D.L. Pyrin binds the PSTPIP1/CD2BP1 protein, defining familial Mediterranean fever and PAPA syndrome as disorders in the same pathway. Proc. Natl. Acad. Sci. USA 2003, 100, 13501-13506. [CrossRef] [PubMed]

52. Kim, M.L.; Chae, J.J.; Park, Y.H.; De Nardo, D.; Stirzaker, R.A.; Ko, H.J.; Tye, H.; Cengia, L.; DiRago, L.; Metcalf, D.; et al. Aberrant actin depolymerization triggers the pyrin inflammasome and autoinflammatory disease that is dependent on IL-18, not IL-1beta. J. Exp. Med. 2015, 212, 927-938. [CrossRef] [PubMed]

53. Minkiewicz, J.; de Rivero Vaccari, J.P.; Keane, R.W. Human astrocytes express a novel NLRP2 inflammasome. Glia 2013, 61, 1113-1121. [CrossRef] [PubMed]

54. Matsuoka, Y.; Yamashita, A.; Matsuda, M.; Kawai, K.; Sawa, T.; Amaya, F. NLRP2 inflammasome in dorsal root ganglion as a novel molecular platform that produces inflammatory pain hypersensitivity. Pain 2019, 160, 2149-2160. [CrossRef] [PubMed]

55. Elinav, E.; Strowig, T.; Kau, A.L.; Henao-Mejia, J.; Thaiss, C.A.; Booth, C.J.; Peaper, D.R.; Bertin, J.; Eisenbarth, S.C.; Gordon, J.I.; et al. NLRP6 inflammasome regulates colonic microbial ecology and risk for colitis. Cell 2011, 145, 745-757. [CrossRef] [PubMed]

56. Hara, H.; Seregin, S.S.; Yang, D.; Fukase, K.; Chamaillard, M.; Alnemri, E.S.; Inohara, N.; Chen, G.Y.; Nunez, G. The NLRP6 Inflammasome Recognizes Lipoteichoic Acid and Regulates Gram-Positive Pathogen Infection. Cell 2018, 175, 1651-1664.e14. [CrossRef]

57. Khare, S.; Dorfleutner, A.; Bryan, N.B.; Yun, C.; Radian, A.D.; de Almeida, L.; Rojanasakul, Y.; Stehlik, C. An NLRP7-containing inflammasome mediates recognition of microbial lipopeptides in human macrophages. Immunity 2012, 36, 464-476. [CrossRef]

58. Zhu, S.; Ding, S.; Wang, P.; Wei, Z.; Pan, W.; Palm, N.W.; Yang, Y.; Yu, H.; Li, H.B.; Wang, G.; et al. Nlrp9b inflammasome restricts rotavirus infection in intestinal epithelial cells. Nature 2017, 546, 667-670. [CrossRef]

59. Vladimer, G.I.; Weng, D.; Paquette, S.W.; Vanaja, S.K.; Rathinam, V.A.; Aune, M.H.; Conlon, J.E.; Burbage, J.J.; Proulx, M.K.; Liu, Q.; et al. The NLRP12 inflammasome recognizes Yersinia pestis. Immunity 2012, 37, 96-107. [CrossRef]

60. Davis, B.K.; Roberts, R.A.; Huang, M.T.; Willingham, S.B.; Conti, B.J.; Brickey, W.J.; Barker, B.R.; Kwan, M.; Taxman, D.J.; Accavitti-Loper, M.A.; et al. Cutting edge: NLRC5-dependent activation of the inflammasome. J. Immunol. 2011, 186, 1333-1337. [CrossRef]

61. Kerur, N.; Veettil, M.V.; Sharma-Walia, N.; Bottero, V.; Sadagopan, S.; Otageri, P.; Chandran, B. IFI16 acts as a nuclear pathogen sensor to induce the inflammasome in response to Kaposi Sarcoma-associated herpesvirus infection. Cell Host Microbe 2011, 9, 363-375. [CrossRef] [PubMed]

62. Radian, A.D.; Khare, S.; Chu, L.H.; Dorfleutner, A.; Stehlik, C. ATP binding by NLRP7 is required for inflammasome activation in response to bacterial lipopeptides. Mol. Immunol. 2015, 67 Pt 2, 294-302. [CrossRef] 
63. Zhou, Y.; Shah, S.Z.; Yang, L.; Zhang, Z.; Zhou, X.; Zhao, D. Virulent Mycobacterium bovis Beijing Strain Activates the NLRP7 Inflammasome in THP-1 Macrophages. PLoS ONE 2016, 11, e0152853. [CrossRef] [PubMed]

64. Allen, I.C.; Wilson, J.E.; Schneider, M.; Lich, J.D.; Roberts, R.A.; Arthur, J.C.; Woodford, R.M.; Davis, B.K.; Uronis, J.M.; Herfarth, H.H.; et al. NLRP12 suppresses colon inflammation and tumorigenesis through the negative regulation of noncanonical NF-kappaB signaling. Immunity 2012, 36, 742-754. [CrossRef] [PubMed]

65. Lukens, J.R.; Gurung, P.; Shaw, P.J.; Barr, M.J.; Zaki, M.H.; Brown, S.A.; Vogel, P.; Chi, H.; Kanneganti, T.D. The NLRP12 Sensor Negatively Regulates Autoinflammatory Disease by Modulating Interleukin-4 Production in T Cells. Immunity 2015, 42, 654-664. [CrossRef] [PubMed]

66. Zaki, M.H.; Vogel, P.; Malireddi, R.K.; Body-Malapel, M.; Anand, P.K.; Bertin, J.; Green, D.R.; Lamkanfi, M.; Kanneganti, T.D. The NOD-like receptor NLRP12 attenuates colon inflammation and tumorigenesis. Cancer Cell 2011, 20, 649-660. [CrossRef]

67. Hagar, J.A.; Powell, D.A.; Aachoui, Y.; Ernst, R.K.; Miao, E.A. Cytoplasmic LPS activates caspase-11: Implications in TLR4-independent endotoxic shock. Science 2013, 341, 1250-1253. [CrossRef]

68. Kayagaki, N.; Warming, S.; Lamkanfi, M.; Vande Walle, L.; Louie, S.; Dong, J.; Newton, K.; Qu, Y.; Liu, J.; Heldens, S.; et al. Non-canonical inflammasome activation targets caspase-11. Nature 2011, 479, 117-121. [CrossRef]

69. Kayagaki, N.; Wong, M.T.; Stowe, I.B.; Ramani, S.R.; Gonzalez, L.C.; Akashi-Takamura, S.; Miyake, K.; Zhang, J.; Lee, W.P.; Muszynski, A.; et al. Noncanonical inflammasome activation by intracellular LPS independent of TLR4. Science 2013, 341, 1246-1249. [CrossRef]

70. Casson, C.N.; Yu, J.; Reyes, V.M.; Taschuk, F.O.; Yadav, A.; Copenhaver, A.M.; Nguyen, H.T.; Collman, R.G.; Shin, S. Human caspase-4 mediates noncanonical inflammasome activation against gram-negative bacterial pathogens. Proc. Natl. Acad. Sci. USA 2015, 112, 6688-6693. [CrossRef]

71. Schmid-Burgk, J.L.; Gaidt, M.M.; Schmidt, T.; Ebert, T.S.; Bartok, E.; Hornung, V. Caspase-4 mediates non-canonical activation of the NLRP3 inflammasome in human myeloid cells. Eur. J. Immunol. 2015, 45, 2911-2917. [CrossRef] [PubMed]

72. Sollberger, G.; Strittmatter, G.E.; Kistowska, M.; French, L.E.; Beer, H.D. Caspase-4 is required for activation of inflammasomes. J. Immunol. 2012, 188, 1992-2000. [CrossRef] [PubMed]

73. Vigano, E.; Diamond, C.E.; Spreafico, R.; Balachander, A.; Sobota, R.M.; Mortellaro, A. Human caspase-4 and caspase-5 regulate the one-step non-canonical inflammasome activation in monocytes. Nat. Commun. 2015, 6, 8761. [CrossRef] [PubMed]

74. Aachoui, Y.; Leaf, I.A.; Hagar, J.A.; Fontana, M.F.; Campos, C.G.; Zak, D.E.; Tan, M.H.; Cotter, P.A.; Vance, R.E.; Aderem, A.; et al. Caspase-11 protects against bacteria that escape the vacuole. Science 2013, 339, 975-978. [CrossRef]

75. Man, S.M.; Karki, R.; Sasai, M.; Place, D.E.; Kesavardhana, S.; Temirov, J.; Frase, S.; Zhu, Q.; Malireddi, R.K.S.; Kuriakose, T.; et al. IRGB10 Liberates Bacterial Ligands for Sensing by the AIM2 and Caspase-11-NLRP3 Inflammasomes. Cell 2016, 167, 382-396.e17. [CrossRef]

76. Pilla, D.M.; Hagar, J.A.; Haldar, A.K.; Mason, A.K.; Degrandi, D.; Pfeffer, K.; Ernst, R.K.; Yamamoto, M.; Miao, E.A.; Coers, J. Guanylate binding proteins promote caspase-11-dependent pyroptosis in response to cytoplasmic LPS. Proc. Natl. Acad. Sci. USA 2014, 111, 6046-6051. [CrossRef]

77. Santos, J.C.; Dick, M.S.; Lagrange, B.; Degrandi, D.; Pfeffer, K.; Yamamoto, M.; Meunier, E.; Pelczar, P.; Henry, T.; Broz, P. LPS targets host guanylate-binding proteins to the bacterial outer membrane for non-canonical inflammasome activation. EMBO J. 2018, 37, e98089. [CrossRef]

78. Vanaja, S.K.; Russo, A.J.; Behl, B.; Banerjee, I.; Yankova, M.; Deshmukh, S.D.; Rathinam, V.A.K. Bacterial Outer Membrane Vesicles Mediate Cytosolic Localization of LPS and Caspase-11 Activation. Cell 2016, 165, 1106-1119. [CrossRef]

79. Xu, J.; Jiang, Y.; Wang, J.; Shi, X.; Liu, Q.; Liu, Z.; Li, Y.; Scott, M.J.; Xiao, G.; Li, S.; et al. Macrophage endocytosis of high-mobility group box 1 triggers pyroptosis. Cell Death Differ. 2014, 21, 1229-1239. [CrossRef]

80. Akhter, A.; Caution, K.; Abu Khweek, A.; Tazi, M.; Abdulrahman, B.A.; Abdelaziz, D.H.; Voss, O.H.; Doseff, A.I.; Hassan, H.; Azad, A.K.; et al. Caspase-11 promotes the fusion of phagosomes harboring pathogenic bacteria with lysosomes by modulating actin polymerization. Immunity 2012, 37, 35-47. [CrossRef] 
81. Broz, P.; Ruby, T.; Belhocine, K.; Bouley, D.M.; Kayagaki, N.; Dixit, V.M.; Monack, D.M. Caspase-11 increases susceptibility to Salmonella infection in the absence of caspase-1. Nature 2012, 490, 288-291. [CrossRef] [PubMed]

82. Krause, K.; Caution, K.; Badr, A.; Hamilton, K.; Saleh, A.; Patel, K.; Seveau, S.; Hall-Stoodley, L.; Hegazi, R.; Zhang, X.; et al. CASP4/caspase-11 promotes autophagosome formation in response to bacterial infection. Autophagy 2018, 14, 1928-1942. [CrossRef] [PubMed]

83. Meunier, E.; Broz, P. Interferon-induced guanylate-binding proteins promote cytosolic lipopolysaccharide detection by caspase-11. DNA Cell Biol. 2015, 34, 1-5. [CrossRef] [PubMed]

84. Meunier, E.; Dick, M.S.; Dreier, R.F.; Schurmann, N.; Kenzelmann Broz, D.; Warming, S.; Roose-Girma, M.; Bumann, D.; Kayagaki, N.; Takeda, K.; et al. Caspase-11 activation requires lysis of pathogen-containing vacuoles by IFN-induced GTPases. Nature 2014, 509, 366-370. [CrossRef]

85. Shi, J.; Zhao, Y.; Wang, Y.; Gao, W.; Ding, J.; Li, P.; Hu, L.; Shao, F. Inflammatory caspases are innate immune receptors for intracellular LPS. Nature 2014, 514, 187-192. [CrossRef]

86. Hu, Z.; Yan, C.; Liu, P.; Huang, Z.; Ma, R.; Zhang, C.; Wang, R.; Zhang, Y.; Martinon, F.; Miao, D.; et al. Crystal structure of NLRC4 reveals its autoinhibition mechanism. Science 2013, 341, 172-175. [CrossRef]

87. Man, S.M.; Kanneganti, T.D. Converging roles of caspases in inflammasome activation, cell death and innate immunity. Nat. Rev. Immunol. 2016, 16, 7-21. [CrossRef]

88. Kesavardhana, S.; Kanneganti, T.D. Mechanisms governing inflammasome activation, assembly and pyroptosis induction. Int. Immunol. 2017, 29, 201-210. [CrossRef]

89. Chu, L.H.; Gangopadhyay, A.; Dorfleutner, A.; Stehlik, C. An updated view on the structure and function of PYRIN domains. Apoptosis 2015, 20, 157-173. [CrossRef]

90. Gambin, Y.; Giles, N.; O'Carroll, A.; Polinkovsky, M.; Hunter, D.; Sierecki, E. Single-Molecule Fluorescence Reveals the Oligomerization and Folding Steps Driving the Prion-like Behavior of ASC. J. Mol. Biol. 2018, 430, 491-508. [CrossRef]

91. Cai, X.; Chen, J.; Xu, H.; Liu, S.; Jiang, Q.X.; Halfmann, R.; Chen, Z.J. Prion-like polymerization underlies signal transduction in antiviral immune defense and inflammasome activation. Cell 2014, 156, 1207-1222. [CrossRef] [PubMed]

92. Lu, A.; Magupalli, V.G.; Ruan, J.; Yin, Q.; Atianand, M.K.; Vos, M.R.; Schroder, G.F.; Fitzgerald, K.A.; Wu, H.; Egelman, E.H. Unified polymerization mechanism for the assembly of ASC-dependent inflammasomes. Cell 2014, 156, 1193-1206. [CrossRef] [PubMed]

93. Sborgi, L.; Ravotti, F.; Dandey, V.P.; Dick, M.S.; Mazur, A.; Reckel, S.; Chami, M.; Scherer, S.; Huber, M.; Bockmann, A.; et al. Structure and assembly of the mouse ASC inflammasome by combined NMR spectroscopy and cryo-electron microscopy. Proc. Natl. Acad. Sci. USA 2015, 112, 13237-13242. [CrossRef] [PubMed]

94. Elliott, J.M.; Rouge, L.; Wiesmann, C.; Scheer, J.M. Crystal structure of procaspase-1 zymogen domain reveals insight into inflammatory caspase autoactivation. J. Biol. Chem. 2009, 284, 6546-6553. [CrossRef]

95. Salvesen, G.S.; Dixit, V.M. Caspase activation: The induced-proximity model. Proc. Natl. Acad. Sci. USA 1999, 96, 10964-10967. [CrossRef]

96. Kesavardhana, S.; Malireddi, R.K.S.; Kanneganti, T.D. Caspases in Cell Death, Inflammation, and Pyroptosis. Annu. Rev. Immunol. 2020, 38, 567-595. [CrossRef]

97. Van Opdenbosch, N.; Lamkanfi, M. Caspases in Cell Death, Inflammation, and Disease. Immunity 2019, 50, $1352-1364$. [CrossRef]

98. Stehlik, C.; Lee, S.H.; Dorfleutner, A.; Stassinopoulos, A.; Sagara, J.; Reed, J.C. Apoptosis-associated speck-like protein containing a caspase recruitment domain is a regulator of procaspase-1 activation. J. Immunol. 2003, 171, 6154-6163. [CrossRef]

99. Srinivasula, S.M.; Poyet, J.L.; Razmara, M.; Datta, P.; Zhang, Z.; Alnemri, E.S. The PYRIN-CARD protein ASC is an activating adaptor for caspase-1. J. Biol. Chem. 2002, 277, 21119-21122. [CrossRef]

100. Zhang, L.; Chen, S.; Ruan, J.; Wu, J.; Tong, A.B.; Yin, Q.; Li, Y.; David, L.; Lu, A.; Wang, W.L.; et al. Cryo-EM structure of the activated NAIP2-NLRC4 inflammasome reveals nucleated polymerization. Science 2015, 350, 404-409. [CrossRef]

101. Hu, Z.; Zhou, Q.; Zhang, C.; Fan, S.; Cheng, W.; Zhao, Y.; Shao, F.; Wang, H.W.; Sui, S.F.; Chai, J. Structural and biochemical basis for induced self-propagation of NLRC4. Science 2015, 350, 399-404. [CrossRef] [PubMed] 
102. Halff, E.F.; Diebolder, C.A.; Versteeg, M.; Schouten, A.; Brondijk, T.H.; Huizinga, E.G. Formation and structure of a NAIP5-NLRC4 inflammasome induced by direct interactions with conserved N- and C-terminal regions of flagellin. J. Biol. Chem. 2012, 287, 38460-38472. [CrossRef]

103. Fernandes-Alnemri, T.; Wu, J.; Yu, J.W.; Datta, P.; Miller, B.; Jankowski, W.; Rosenberg, S.; Zhang, J.; Alnemri, E.S. The pyroptosome: A supramolecular assembly of ASC dimers mediating inflammatory cell death via caspase-1 activation. Cell Death Differ. 2007, 14, 1590-1604. [CrossRef] [PubMed]

104. Bryan, N.B.; Dorfleutner, A.; Rojanasakul, Y.; Stehlik, C. Activation of inflammasomes requires intracellular redistribution of the apoptotic speck-like protein containing a caspase recruitment domain. J. Immunol. 2009, 182, 3173-3182. [CrossRef] [PubMed]

105. Kostura, M.J.; Tocci, M.J.; Limjuco, G.; Chin, J.; Cameron, P.; Hillman, A.G.; Chartrain, N.A.; Schmidt, J.A. Identification of a monocyte specific pre-interleukin 1 beta convertase activity. Proc. Natl. Acad. Sci. USA 1989, 86, 5227-5231. [CrossRef]

106. Li, P.; Allen, H.; Banerjee, S.; Franklin, S.; Herzog, L.; Johnston, C.; McDowell, J.; Paskind, M.; Rodman, L.; Salfeld, J.; et al. Mice deficient in IL-1b-converting enzyme are defective in production of mature IL-1b and resistant to endotoxic shock. Cell 1995, 80, 401-411. [CrossRef]

107. Thornberry, N.A.; Bull, H.G.; Calaycay, J.R.; Chapman, K.T.; Howard, A.D.; Kostura, M.J.; Miller, D.K.; Molineaux, S.M.; Weidner, J.R.; Aunins, J.; et al. A novel heterodimeric cysteine protease is required for interleukin-1 beta processing in monocytes. Nature 1992, 356, 768-774. [CrossRef]

108. Baroja-Mazo, A.; Compan, V.; Martin-Sanchez, F.; Tapia-Abellan, A.; Couillin, I.; Pelegrin, P. Early endosome autoantigen 1 regulates IL-1beta release upon caspase-1 activation independently of gasdermin D membrane permeabilization. Sci. Rep. 2019, 9, 5788. [CrossRef]

109. Monteleone, M.; Stanley, A.C.; Chen, K.W.; Brown, D.L.; Bezbradica, J.S.; von Pein, J.B.; Holley, C.L.; Boucher, D.; Shakespear, M.R.; Kapetanovic, R.; et al. Interleukin-1beta Maturation Triggers Its Relocation to the Plasma Membrane for Gasdermin-D-Dependent and -Independent Secretion. Cell Rep. 2018, 24, 1425-1433. [CrossRef]

110. Fink, S.L.; Cookson, B.T. Caspase-1-dependent pore formation during pyroptosis leads to osmotic lysis of infected host macrophages. Cell Microbiol. 2006, 8, 1812-1825. [CrossRef]

111. Evavold, C.L.; Ruan, J.; Tan, Y.; Xia, S.; Wu, H.; Kagan, J.C. The Pore-Forming Protein Gasdermin D Regulates Interleukin-1 Secretion from Living Macrophages. Immunity 2018, 48, 35-44.e6. [CrossRef] [PubMed]

112. Baroja-Mazo, A.; Martin-Sanchez, F.; Gomez, A.I.; Martinez, C.M.; Amores-Iniesta, J.; Compan, V.; Barbera-Cremades, M.; Yague, J.; Ruiz-Ortiz, E.; Anton, J.; et al. The NLRP3 inflammasome is released as a particulate danger signal that amplifies the inflammatory response. Nat. Immunol. 2014, 15, 738-748. [CrossRef] [PubMed]

113. Franklin, B.S.; Bossaller, L.; De Nardo, D.; Ratter, J.M.; Stutz, A.; Engels, G.; Brenker, C.; Nordhoff, M.; Mirandola, S.R.; Al-Amoudi, A.; et al. The adaptor ASC has extracellular and 'prionoid' activities that propagate inflammation. Nat. Immunol. 2014, 15, 727-737. [CrossRef] [PubMed]

114. He, W.T.; Wan, H.; Hu, L.; Chen, P.; Wang, X.; Huang, Z.; Yang, Z.H.; Zhong, C.Q.; Han, J. Gasdermin D is an executor of pyroptosis and required for interleukin-1beta secretion. Cell Res. 2015, 25, 1285-1298. [CrossRef] [PubMed]

115. Kayagaki, N.; Stowe, I.B.; Lee, B.L.; O’Rourke, K.; Anderson, K.; Warming, S.; Cuellar, T.; Haley, B.; Roose-Girma, M.; Phung, Q.T.; et al. Caspase-11 cleaves gasdermin D for non-canonical inflammasome signalling. Nature 2015, 526, 666-671. [CrossRef] [PubMed]

116. Aglietti, R.A.; Estevez, A.; Gupta, A.; Ramirez, M.G.; Liu, P.S.; Kayagaki, N.; Ciferri, C.; Dixit, V.M.; Dueber, E.C. GsdmD p30 elicited by caspase-11 during pyroptosis forms pores in membranes. Proc. Natl. Acad. Sci. USA 2016, 113, 7858-7863. [CrossRef] [PubMed]

117. Chen, X.; He, W.T.; Hu, L.; Li, J.; Fang, Y.; Wang, X.; Xu, X.; Wang, Z.; Huang, K.; Han, J. Pyroptosis is driven by non-selective gasdermin-D pore and its morphology is different from MLKL channel-mediated necroptosis. Cell Res. 2016, 26, 1007-1020. [CrossRef]

118. Ding, J.; Wang, K.; Liu, W.; She, Y.; Sun, Q.; Shi, J.; Sun, H.; Wang, D.C.; Shao, F. Pore-forming activity and structural autoinhibition of the gasdermin family. Nature 2016, 535, 111-116. [CrossRef]

119. Liu, X.; Zhang, Z.; Ruan, J.; Pan, Y.; Magupalli, V.G.; Wu, H.; Lieberman, J. Inflammasome-activated gasdermin D causes pyroptosis by forming membrane pores. Nature 2016, 535, 153-158. [CrossRef] 
120. Russo, H.M.; Rathkey, J.; Boyd-Tressler, A.; Katsnelson, M.A.; Abbott, D.W.; Dubyak, G.R. Active Caspase-1 Induces Plasma Membrane Pores That Precede Pyroptotic Lysis and Are Blocked by Lanthanides. J. Immunol. 2016, 197, 1353-1367. [CrossRef]

121. Sborgi, L.; Ruhl, S.; Mulvihill, E.; Pipercevic, J.; Heilig, R.; Stahlberg, H.; Farady, C.J.; Muller, D.J.; Broz, P.; Hiller, S. GSDMD membrane pore formation constitutes the mechanism of pyroptotic cell death. EMBO J. 2016, 35, 1766-1778. [CrossRef] [PubMed]

122. Rogers, C.; Erkes, D.A.; Nardone, A.; Aplin, A.E.; Fernandes-Alnemri, T.; Alnemri, E.S. Gasdermin pores permeabilize mitochondria to augment caspase-3 activation during apoptosis and inflammasome activation. Nat. Commun. 2019, 10, 1689. [CrossRef] [PubMed]

123. Ruhl, S.; Broz, P. Caspase-11 activates a canonical NLRP3 inflammasome by promoting $K(+)$ efflux. Eur. J. Immunol. 2015, 45, 2927-2936. [CrossRef] [PubMed]

124. Munoz-Planillo, R.; Kuffa, P.; Martinez-Colon, G.; Smith, B.L.; Rajendiran, T.M.; Nunez, G. K(+) efflux is the common trigger of NLRP3 inflammasome activation by bacterial toxins and particulate matter. Immunity 2013, 38, 1142-1153. [CrossRef]

125. Yang, D.; He, Y.; Munoz-Planillo, R.; Liu, Q.; Nunez, G. Caspase-11 Requires the Pannexin-1 Channel and the Purinergic P2X7 Pore to Mediate Pyroptosis and Endotoxic Shock. Immunity 2015, 43, 923-932. [CrossRef]

126. Chen, K.W.; Demarco, B.; Broz, P. Pannexin-1 promotes NLRP3 activation during apoptosis but is dispensable for canonical or noncanonical inflammasome activation. Eur. J. Immunol. 2020, 50, 170-177. [CrossRef]

127. Py, B.F.; Jin, M.; Desai, B.N.; Penumaka, A.; Zhu, H.; Kober, M.; Dietrich, A.; Lipinski, M.M.; Henry, T.; Clapham, D.E.; et al. Caspase-11 controls interleukin-1beta release through degradation of TRPC1. Cell Rep. 2014, 6, 1122-1128. [CrossRef]

128. Platnich, J.M.; Chung, H.; Lau, A.; Sandall, C.F.; Bondzi-Simpson, A.; Chen, H.M.; Komada, T.; Trotman-Grant, A.C.; Brandelli, J.R.; Chun, J.; et al. Shiga Toxin/Lipopolysaccharide Activates Caspase-4 and Gasdermin D to Trigger Mitochondrial Reactive Oxygen Species Upstream of the NLRP3 Inflammasome. Cell Rep. 2018, 25, 1525-1536.e7. [CrossRef]

129. Broderick, L.; De Nardo, D.; Franklin, B.S.; Hoffman, H.M.; Latz, E. The inflammasomes and autoinflammatory syndromes. Annu. Rev. Pathol. 2015, 10, 395-424. [CrossRef]

130. Hoffman, H.M.; Brydges, S.D. Genetic and molecular basis of inflammasome-mediated disease. J. Biol. Chem. 2011, 286, 10889-10896. [CrossRef]

131. Masters, S.L.; Simon, A.; Aksentijevich, I.; Kastner, D.L. Horror autoinflammaticus: The molecular pathophysiology of autoinflammatory disease $\left(^{*}\right)$. Annu. Rev. Immunol. 2009, 27, 621-668. [CrossRef] [PubMed]

132. Yu, C.H.; Moecking, J.; Geyer, M.; Masters, S.L. Mechanisms of NLRP1-Mediated Autoinflammatory Disease in Humans and Mice. J. Mol. Biol. 2018, 430, 142-152. [CrossRef] [PubMed]

133. Romberg, N.; Vogel, T.P.; Canna, S.W. NLRC4 inflammasomopathies. Curr. Opin. Allergy Clin. Immunol. 2017, 17, 398-404. [CrossRef] [PubMed]

134. Carriere, J.; Dorfleutner, A.; Stehlik, C. NLRP7, From Inflammasome Regulation to Human Disease. Immunology 2020, in press.

135. Schnappauf, O.; Chae, J.J.; Kastner, D.L.; Aksentijevich, I. The Pyrin Inflammasome in Health and Disease. Front. Immunol. 2019, 10, 1745. [CrossRef]

136. Christgen, S.; Place, D.E.; Kanneganti, T.D. Toward targeting inflammasomes: Insights into their regulation and activation. Cell Res. 2020, 30, 315-327. [CrossRef]

137. Zahid, A.; Li, B.; Kombe, A.J.K.; Jin, T.; Tao, J. Pharmacological Inhibitors of the NLRP3 Inflammasome. Front. Immunol. 2019, 10, 2538. [CrossRef]

138. Jin, T.; Xiao, T.S. Activation and assembly of the inflammasomes through conserved protein domain families. Apoptosis 2015, 20, 151-156. [CrossRef]

139. Kersse, K.; Verspurten, J.; Vanden Berghe, T.; Vandenabeele, P. The death-fold superfamily of homotypic interaction motifs. Trends Biochem. Sci. 2011, 36, 541-552. [CrossRef]

140. Park, H.H.; Lo, Y.C.; Lin, S.C.; Wang, L.; Yang, J.K.; Wu, H. The death domain superfamily in intracellular signaling of apoptosis and inflammation. Annu. Rev. Immunol. 2007, 25, 561-586. [CrossRef]

141. Kao, W.P.; Yang, C.Y.; Su, T.W.; Wang, Y.T.; Lo, Y.C.; Lin, S.C. The versatile roles of CARDs in regulating apoptosis, inflammation, and NF-kappaB signaling. Apoptosis 2015, 20, 174-195. [CrossRef] [PubMed] 
142. Stehlik, C.; Dorfleutner, A. COPs and POPs: Modulators of inflammasome activity. J. Immunol. 2007, 179, 7993-7998. [CrossRef] [PubMed]

143. Atianand, M.K.; Fuchs, T.; Harton, J.A. Recent evolution of the NF-kappaB and inflammasome regulating protein POP2 in primates. BMC Evol. Biol. 2011, 11, 56. [CrossRef] [PubMed]

144. Khare, S.; Ratsimandresy, R.A.; de Almeida, L.; Cuda, C.M.; Rellick, S.L.; Misharin, A.V.; Wallin, M.C.; Gangopadhyay, A.; Forte, E.; Gottwein, E.; et al. The PYRIN domain-only protein POP3 inhibits ALR inflammasomes and regulates responses to infection with DNA viruses. Nat. Immunol. 2014, 15, 343-353. [CrossRef]

145. Porter, K.A.; Duffy, E.B.; Nyland, P.; Atianand, M.K.; Sharifi, H.; Harton, J.A. The CLRX.1/NOD24 (NLRP2P) pseudogene codes a functional negative regulator of NF-kappaB, pyrin-only protein 4. Genes Immun. 2014, 15, 392-403. [CrossRef]

146. Stehlik, C.; Krajewska, M.; Welsh, K.; Krajewski, S.; Godzik, A.; Reed, J.C. The PAAD/PYRIN-only protein POP1/ASC2 is a modulator of ASC-mediated NF-kB and pro-Caspase-1 regulation. Biochem. J. 2003, 373, 101-113. [CrossRef]

147. Srimathi, T.; Robbins, S.L.; Dubas, R.L.; Chang, H.; Cheng, H.; Roder, H.; Park, Y.C. Mapping of POP1-binding site on pyrin domain of ASC. J. Biol. Chem. 2008, 283, 15390-15398. [CrossRef]

148. Choi, J.Y.; Kim, C.M.; Seo, E.K.; Bhat, E.A.; Jang, T.H.; Lee, J.H.; Park, H.H. Crystal structure of human POP1 and its distinct structural feature for PYD domain. Biochem. Biophys. Res. Commun. 2015, 460, 957-963. [CrossRef]

149. De Almeida, L.; Khare, S.; Misharin, A.V.; Patel, R.; Ratsimandresy, R.A.; Wallin, M.C.; Perlman, H.; Greaves, D.R.; Hoffman, H.M.; Dorfleutner, A.; et al. The PYRIN Domain-only Protein POP1 Inhibits Inflammasome Assembly and Ameliorates Inflammatory Disease. Immunity 2015, 43, 264-276. [CrossRef]

150. Bedoya, F.; Sandler, L.L.; Harton, J.A. Pyrin-only protein 2 modulates NF-kappaB and disrupts ASC:CLR interactions. J. Immunol. 2007, 178, 3837-3845. [CrossRef]

151. Dorfleutner, A.; Bryan, N.B.; Talbott, S.J.; Funya, K.N.; Rellick, S.L.; Reed, J.C.; Shi, X.; Rojanasakul, Y.; Flynn, D.C.; Stehlik, C. Cellular pyrin domain-only protein 2 is a candidate regulator of inflammasome activation. Infect. Immun. 2007, 75, 1484-1492. [CrossRef] [PubMed]

152. Atianand, M.K.; Harton, J.A. Uncoupling of Pyrin-only protein 2 (POP2)-mediated dual regulation of NF-kappaB and the inflammasome. J. Biol. Chem. 2011, 286, 40536-40547. [CrossRef] [PubMed]

153. Periasamy, S.; Porter, K.A.; Atianand, M.K.; Le, H.T.; Earley, S.; Duffy, E.B.; Haller, M.C.; Chin, H.; Harton, J.A. Pyrin-only protein 2 limits inflammation but improves protection against bacteria. Nat. Commun. 2017, 8, 15564. [CrossRef] [PubMed]

154. Ratsimandresy, R.A.; Chu, L.H.; Khare, S.; de Almeida, L.; Gangopadhyay, A.; Indramohan, M.; Misharin, A.V.; Greaves, D.R.; Perlman, H.; Dorfleutner, A.; et al. The PYRIN domain-only protein POP2 inhibits inflammasome priming and activation. Nat. Commun. 2017, 8, 15556. [CrossRef]

155. Schattgen, S.A.; Fitzgerald, K.A. The PYHIN protein family as mediators of host defenses. Immunol. Rev. 2011, 243, 109-118. [CrossRef]

156. Ludlow, L.E.; Johnstone, R.W.; Clarke, C.J. The HIN-200 family: More than interferon-inducible genes? Exp. Cell Res. 2005, 308, 1-17. [CrossRef]

157. Lee, S.H.; Stehlik, C.; Reed, J.C. Cop, a caspase recruitment domain-containing protein and inhibitor of caspase-1 activation processing. J. Biol. Chem. 2001, 276, 34495-34500. [CrossRef]

158. Druilhe, A.; Srinivasula, S.M.; Razmara, M.; Ahmad, M.; Alnemri, E.S. Regulation of IL-1beta generation by Pseudo-ICE and ICEBERG, two dominant negative caspase recruitment domain proteins. Cell Death Differ. 2001, 8, 649-657. [CrossRef]

159. Karasawa, T.; Kawashima, A.; Usui, F.; Kimura, H.; Shirasuna, K.; Inoue, Y.; Komada, T.; Kobayashi, M.; Mizushina, Y.; Sagara, J.; et al. Oligomerized CARD16 promotes caspase-1 assembly and IL-1beta processing. FEBS Open Bio 2015, 5, 348-356. [CrossRef]

160. Lamkanfi, M.; Denecker, G.; Kalai, M.; D’Hondt, K.; Meeus, A.; Declercq, W.; Saelens, X.; Vandenabeele, P. INCA, a novel human caspase recruitment domain protein that inhibits interleukin-1beta generation. J. Biol. Chem. 2001, 279, 51729-51738. [CrossRef]

161. Lu, A.; Li, Y.; Schmidt, F.I.; Yin, Q.; Chen, S.; Fu, T.M.; Tong, A.B.; Ploegh, H.L.; Mao, Y.; Wu, H. Molecular basis of caspase-1 polymerization and its inhibition by a new capping mechanism. Nat. Struct. Mol. Biol. 2016, 23, 416-425. [CrossRef] [PubMed] 
162. Humke, E.W.; Shriver, S.K.; Starovasnik, M.A.; Fairbrother, W.J.; Dixit, V.M. ICEBERG: A novel inhibitor of interleukin-1beta generation. Cell 2000, 103, 99-111. [CrossRef]

163. Wilson, K.P.; Black, J.A.; Thomson, J.A.; Kim, E.E.; Griffith, J.P.; Navia, M.A.; Murcko, M.A.; Chambers, S.P.; Aldape, R.A.; Raybuck, S.A.; et al. Structure and mechanism of interleukin-1 beta converting enzyme. Nature 1994, 370, 270-275. [CrossRef] [PubMed]

164. Goblos, A.; Danis, J.; Vas, K.; Bata-Csorgo, Z.; Kemeny, L.; Szell, M. Keratinocytes express functional CARD18, a negative regulator of inflammasome activation, and its altered expression in psoriasis may contribute to disease pathogenesis. Mol. Immunol. 2016, 73, 10-18. [CrossRef] [PubMed]

165. Qin, H.; Jin, J.; Fischer, H.; Mildner, M.; Gschwandtner, M.; Mlitz, V.; Eckhart, L.; Tschachler, E. The caspase-1 inhibitor CARD18 is specifically expressed during late differentiation of keratinocytes and its expression is lost in lichen planus. J. Dermatol. Sci. 2017, 87, 176-182. [CrossRef] [PubMed]

166. Aral, K.; Berdeli, E.; Cooper, P.R.; Milward, M.R.; Kapila, Y.; Karadede Unal, B.; Aral, C.A.; Berdeli, A. Differential expression of inflammasome regulatory transcripts in periodontal disease. J. Periodontol. 2020, 91, 606-616. [CrossRef] [PubMed]

(C) 2020 by the authors. Licensee MDPI, Basel, Switzerland. This article is an open access article distributed under the terms and conditions of the Creative Commons Attribution (CC BY) license (http://creativecommons.org/licenses/by/4.0/). 